\title{
Observations of an instrumented pile-raft foundation in weak rock
}

\author{
C. F. Leung, R. Radhakrishnan and Y. K. Wong
}

\section{Mr M. J. Tomlinson, Consulting Engineer}

Very deep tropical weathering is a feature of the sedimentary rocks which underlie the southern part of Singapore City. The information given in the Paper on the physical properties of the rock is typical in that it shows the wide variation in strength and compressibility with no trend to any appreciable increase in rock quality over a depth of $30 \mathrm{~m}$ or more below rock head. I had experience with the foundation design for the 50-storey Development Bank of Singapore where the weathering extended to depths of more than $70 \mathrm{~m}$ below rock head. On this site, as in many others along the old shore line, the weathered rocks are overlain by deep soft marine clays, and it was necessary to sink hand excavated shafts of $7.32 \mathrm{~m}$ dia. to depths of up to $64 \mathrm{~m}$ below street level to reach rock of a quality suitable for the very heavily loaded column foundations.

48. In the case of the PSA building the rock surface was within a few metres of ground level. However, the Authors state that a piled raft foundation was adopted instead of an unpiled basement raft in order to avoid the risk of unacceptably large differential settlements caused by the variability in rock quality.

49. The Authors' Paper is a valuable case history of the behaviour of a large heavily loaded pile group founded in weak rock but in view of the very small recorded settlements it does appear, with hindsight, that an unpiled raft at basement level could have been used. The total settlements would have been larger but the differential movement should have been within acceptable limits.

50. In deeply weathered rocks of the type present in Singapore piling is a difficult problem when heavy loads utilizing the maximum pile bearing capacity are to be carried. Weathering takes the form of core stones of fairly strong rock surrounded by a matrix of completely or highly weathered rock having the consistency of a stiff or hard claey silt. Driven piles may refuse further penetration on a core stone before reaching the design toe level. In the case of bored piles it is difficult to judge the required depth of the rock socket from observations made while rotary drilling. It has been necessary in Singapore to adopt rather crude rules-of-thumb which do not always give an economical socket length. Perhaps the Authors could comment on these rules.

51. The values of the pressuremeter modulus of the weathered rock in Table 1 of the Paper when plotted against depth indicate an increase in the average modulus from about $220 \mathrm{MN} / \mathrm{m}^{2}$ at basement level to $500 \mathrm{MN} / \mathrm{m}^{2}$ at $9 \mathrm{~m}$ below this level. Using these values in conjunction with the influence factors established by Meigh $^{22}$ for rocks having a linear increase in deformation modulus with

Paper published: Proc. Instn Civ. Engrs, Part 1, 1988, 84, Aug., 693-711. 


\section{DISCUSSION}

increasing depth, I have calculated the average settlement of a rigid unpiled basement raft to be in the range $15-30 \mathrm{~mm}$. Long-term creep compression would probably increase these values by about $50 \%$. The range in the calculated settlements is due to my uncertainty concerning the total weight of the building. The average of the pile loads in Table 2 taken in conjunction with the Authors' statement that the piles were carrying $95 \%$ of the building load suggests a total net load of about $1800 \mathrm{MN}$, whereas the average raft contact pressure of about $80 \mathrm{kN} / \mathrm{m}^{2}$ when it was carrying $5 \%$ of the building load suggests that the latter was $4000 \mathrm{MN}$. Could the Authors state the net load used for their design?

52. Another method of determining the settlement of foundations in weak rocks is to obtain the deformation modulus from empirical ratios between the modulus and the unconfined compression strength of the intact rock, taking into account the fracture frequency or joint spacing of the rock mass. The average strength from Fig. 5 is about $12 \mathrm{MN} / \mathrm{m}^{2}$. The modulus ratio for poorly cemented sandstones and cemented mudstones and shales is 150 . For the average RQD of $30 \%$ indicated by Fig. 4, Hobbs $^{23}$ gives a mass factor of 0.2 . Hence the deformation modulus is $360 \mathrm{MN} / \mathrm{m}^{2}$ which compares well with the average of the pressuremeter modulus readings. Although the method of determining the compressibility of a weathered rock mass from relationships with the unconfined compression strength of the intact rock is rather crude it can be used for practical foundation design because the total settlements are usually small relative to those experienced with foundations on overconsolidated clays.

53. The Authors have shown that the use of the pressuremeter can be helpful in the determination of the compressibility of weak rock masses and hence to decide whether or not piling is needed in order to limit foundation settlements. Furtherance of its use in Singapore and elsewhere where similar rocks are present should enable engineers to design foundations with greater confidence and economy.

\section{Dr Leung, Mr Radhakrishnan and Mr Wong}

Judging from the small magnitude of recorded settlements for the pile-raft foundation of the PSA building, it may seem that an unpiled basement raft foundation was adequate. Even though analysis performed at the design stage revealed that an unpiled raft of $3 \mathrm{~m}$ thickness was found to be an adequate foundation support system for the building, the final decision to adopt a pile-raft foundation was due to stringent requirements on differential settlement as mentioned in the Paper. Uncertainty of larger differential foundation settlements in the case of an unpiled raft was very much in the mind of the designer as there was a ridge formation spanning across the proposed building area. This made the usual wide variation in strength and compressibility of the sedimentary rock formations in the area even more complicated.

55. Mr Tomlinson has rightly pointed out the potential use of pressuremeter modulus in the determination of compressibility of weak rock masses. The total estimated dead and live loads of the building and raft was $2000 \mathrm{MN}$. Thus according to $\mathrm{Mr}$ Tomlinson's calculations, the average settlement of a rigid unpiled raft would be about $15 \mathrm{~mm}$ and long-term creep compression would probably increase this value by about $50 \%$. Unfortunately for the PSA building project, most of the pressuremeter tests had to be terminated before they reached the plastic phase as high capacity pressuremeter equipments were then unavailable in Singapore. Hence the computed modulus values used in Mr Tomlinson's calculations and the 
resulting settlement estimation are likely to be on the conservative side.

56. The Authors agree with $\mathrm{Mr}$ Tomlinson that the deformation modulus of rock mass $E_{\mathrm{m}}$ can also be estimated from the unconfined compression strength $q_{\mathrm{u}}$ of the intact rock. Based on the load-settlement relationships obtained from load tests on large diameter rock-socketed bored piles at the PSA building site and at a nearby warehouse construction site, Radhakrishnan and Leung ${ }^{24}$ has noted that the relationship of $E_{\mathrm{m}}=215 \sqrt{ } q_{\mathrm{u}}$ proposed by Rowe and Armitage ${ }^{25}$ is satisfactory in determining the deformation modulus of the rock masses at the two sites.

57. In the construction of bored piles in weathered rocks, the rock samples collected for inspection from the drilled shafts are usually highly or completely fractured. This generally leads to inconsistent and hence unrealiable assessment of rock quality as the rock samples could be fractured by the use of heavy chisels or due to the natural weathering process. In the case of the construction of the foundation for the PSA building, some of the drilled shafts were inspected to ensure the in situ rock quality of the rock socket and base. Based on the results of two preliminary instrumented test piles carried out at the site, it was possible to adopt a suitable pile socket length to pile diameter ratio as a guide for the installation of the working piles. This proved to be a helpful guide in the actual installation of the bored piles.

\section{References}

22. MeIGH A. C. The Triassic rocks with particular reference to predicted and observed performance of some major structures. Géotechnique, 1976, 26, No. 3. 393-451.

23. Hobrs N. B. General report and state-of-the-art review. Proc. Conf. on Settlement of Structures, Pentech Press, Cambridge, 1974, 579-609.

24. Radhakrishnan R. and LeUNG C. F. Load transfer behavior of rock-socketed piles, $J$. Geotech. Engng, Am. Soc. Civ. Engrs, 1989, (in press).

25. Rowe R. K. and ARmitage H. H. A design method for drilled piers in soft rock, Can. Geotech. J., 1987, 24, 126-142. 